Tropical Journal of Pharmaceutical Research February 2017; 16 (2): 407-412

ISSN: $1596-5996$ (print); 1596-9827 (electronic)

(c) Pharmacotherapy Group, Faculty of Pharmacy, University of Benin, Benin City, 300001 Nigeria.

All rights reserved.

Available online at http://www.tjpr.org

Original Research Article

http://dx.doi.org/10.4314/tjpr.v16i2.20

\title{
Time-kill profiles and cell-surface morphological effects of crude Polycephalomyces nipponicus Cod-MK1201 mycelial extract against antibiotic-sensitive and -resistant Staphylococcus aureus
}

\author{
Sutthiwan Thammawat ${ }^{1 \star}$, Kusavadee Sangdee ${ }^{1}$ and Aphidech Sangdee ${ }^{2,3}$ \\ ${ }^{1}$ Microbiology Group, Biomedical Sciences Research Unit, Faculty of Medicine, Mahasarakham University, Muang District, \\ Maha Sarakham 44000, ${ }^{2}$ Department of Biology, ${ }^{3}$ Microbiology and Applied Microbiology Research Unit, Faculty of Science, \\ Mahasarakham University, Kantarawichai District, Maha Sarakham 44150, Thailand \\ ${ }^{*}$ For correspondence: Email: tham.sutthi76@gmail.com; Tel: +6686-9890776
}

Revised accepted: 24 January 2017

\begin{abstract}
Purpose: To examine the effect of crude Polycephalomyces nipponicus Cod-MK1201 mycelial extract on the viability and cell surface morphology of methicillin-susceptible Staphylococcus aureus (MSSA) and methicillin-resistant Staphylococcus aureus (MRSA).

Methods: Time-kill assays were conducted by incubating test bacteria with the extract and sampling at selected time points within a $24 \mathrm{~h}$ period. The effects of the extract on MSSA and MRSA ultrastructure were determined using a scanning electron microscope (SEM).

Results: Time-kill assay data indicate a bactericidal effect against both strains of staphylococci. The extracts were rapidly bactericidal at concentrations of $1 \times M I C$ and $2 \times M I C$, achieving complete elimination of the test bacterial strains within $2 \mathrm{~h}$. SEM micrographs of $S$. aureus taken after treatment with various concentrations of the extract revealed extensive morphological alterations to the cell surface of both MSSA and MRSA.

Conclusion: The results confirm the antibacterial activity of $P$. nipponicus Cod-MK1201 mycelial extract. Further research may allow this to be developed as an alternative therapy to alleviate $S$. aureus infection.
\end{abstract}

Keywords: Antibacterial activity, Polycephalomyces nipponicus, Staphylococcus aureus, Time-kill assay, Cell surface morphology

Tropical Journal of Pharmaceutical Research is indexed by Science Citation Index (SciSearch), Scopus, International Pharmaceutical Abstract, Chemical Abstracts, Embase, Index Copernicus, EBSCO, African Index Medicus, JournalSeek, Journal Citation Reports/Science Edition, Directory of Open Access Journals (DOAJ), African Journal Online, Bioline International, Open-J-Gate and Pharmacy Abstracts

\section{INTRODUCTION}

Staphylococcus aureus is a major human pathogen, causing pyogenic infections such as abscesses, and even fatal septicemia [1]. Methicillin-resistant $S$. aureus (MRSA) infections have become an important problem in both the hospital and community requiring vancomycin for effective clinical treatment $[2,3]$. Alarmingly, MRSA strains with reduced susceptibility to vancomycin are now also being reported [4,5]. Moreover, there have been reports of MRSA resistant to chlorhexidine and other disinfectants commonly used for infection control and reducing the spread of MRSA in hospitals [6-8]. To overcome the problem of antibiotic resistance, alternative sources of bioactive compounds are being screened for possible development as the next generation of antibacterial therapies. 
Medicinal mushrooms have been used as traditional remedies for infectious diseases in many tropical countries, and represent a natural source of antimicrobial agents [9]. Cordyceps is a genus of entomopathogenic fungi that are used in traditional Chinese medicine for various health effects including immunomodulatory, anticancer, antioxidant, anti-inflammatory and antimicrobial activities [10-13]. Recently, it was demonstrated that Cordyceps taii extracts have broad-spectrum activity against both bacteria and fungi [14]. Also, a protein isolated from the cultured mycelia of Cordyceps sinensis has been reported to have activity against the bacteria Staphylococcus aureus, Escherichia coli, Proteus vulgaris, , and Salmonella enterica serovar Typhi [15]. The methanol extract from Cordyceps militaris has strong antibacterial and antifungal activity too [10]. These findings indicate that many entomopathogenic fungi produce bioactive compounds effective against microbial pathogens. However, time-kill data and information on the morphological effects of these extracts on bacterial cells is limited.

In a previous study, we isolated the entomopathogenic fungus Cod-MK1201 from a dead cicada nymph and found it to have potent antibacterial activity against both Gram-positive and Gram-negative bacteria [16]. The isolate was subsequently identified as Polycephalomyces nipponicus based on fungal morphology, three regions of ribosomal nuclear DNA (ITS, LSU, $S S U$ ), and four protein-coding regions (rpb1, ef1a, $\beta$-tubulin, ATP6) [17]. However, the bactericidal activity of the crude extract of this isolate has not yet been characterized in terms of the kinetics of bacterial death. Therefore, the aim of the present study was to evaluate the activity of Cod-MK1201 ethanol extract against Grampositive Staphylococcus aureus by the time-kill method. The effect of the ethanol extract on bacterial morphology was also examined.

\section{EXPERIMENTAL}

\section{Microorganisms and antibacterial agent}

Two reference strains of Staphylococcus aureus, methicillin-sensitive Staphylococcus aureus (MSSA) strain DMST 2933 and methicillinresistant Staphylococcus aureus (MRSA) strain DMST 20651 were obtained from the medical microorganism collection at the Department of Medical Sciences Thailand (DMST), Ministry of Public Health, Thailand. These were used in assays evaluating the antibacterial activity of the extract.

\section{Preparation of mycelial extract of Polycephalomyces nipponicus Cod-MK1201}

Mycelial extracts were prepared as described previously by Sandgee et al [16]. Briefly, mycelial discs were cut and inoculated into $25 \mathrm{ml}$ of induced medium, then incubated at $28^{\circ} \mathrm{C}$ with shaking. After 20 days, the mycelium on the surface of the culture medium was collected, dried $\left(50{ }^{\circ} \mathrm{C}\right.$ overnight), powdered, and stored in a screw cap tube. Ethanol $50 \%(\mathrm{v} / \mathrm{v})$ was then added to the dried mycelium, and the mycelial suspension $(100 \mathrm{mg} / \mathrm{ml})$ was sonicated with a high Intensity Ultrasonic Processor (Model VCX750, Newtown, CT, USA). This step was performed on ice as described by Sangdee et al [18].

\section{Time-kill assay}

Time-kill assays were performed as described by White et al [19] and Aiyegoro et al [20], with some modifications regarding the counting of viable cells. MICs were determined by broth microdilution assay as described by Sangdee et al [16]. The extract was incorporated into $0.9 \mathrm{~mL}$ Mueller Hinton broth (MHB) at concentrations of $1.56 \mathrm{mg} / \mathrm{mL}$ ( $0.5 \times \mathrm{MIC}), 3.125 \mathrm{mg} / \mathrm{mL}(1 \times \mathrm{MIC})$ and $6.25 \mathrm{mg} / \mathrm{mL}(2 \times \mathrm{MIC})$. Test tubes of MHB without extract were used as growth controls. Overnight cultures of the bacterial strains at cell densities of approximately $1 \times 10^{8} \mathrm{CFU} / \mathrm{mL}$ were used to inoculate $0.1 \mathrm{~mL}$ volumes of both test and control tubes. The cultures were then incubated in a shaker at $37^{\circ} \mathrm{C}$ for $1,2,4,6$ and $24 \mathrm{~h}$. After each interval, ten-fold serial dilutions were prepared with phosphate buffered saline (PBS), and $0.1 \mathrm{~mL}$ samples were pipetted onto Mueller Hinton agar (MHA) plates in duplicate. Colony counts were performed after $18 \mathrm{~h}$ incubation at $37^{\circ} \mathrm{C}$. Plates with $30-300$ colonies were used for these counts, and the kill rate was determined by plotting $\log _{10}$ viable counts $(\mathrm{CFU} / \mathrm{mL})$ against time. Bactericidal activity was defined as a $\geq 3 \log _{10}$ decrease in CFU/mL of the initial microbial population, while bacteriostatic activity was defined as a $<3 \log _{10}$ decrease in $\mathrm{CFU} / \mathrm{mL}$.

\section{Scanning electron microscopy (SEM)}

Scanning electron microscopy was used to determine the antibacterial effect of the mycelial extract on $S$. aureus cells. Briefly, the test bacteria were cultured in MHB and incubated at $37^{\circ} \mathrm{C}$ with shaking for $3 \mathrm{~h}$. The turbidities of the final inocula were adjusted to the $0.5 \mathrm{McF}$ arland standards. One hundred microliters of each bacterial cell suspension was then added to 900 $\mu \mathrm{L}$ of the mycelial extract (at concentrations of 
$0.5 \times \mathrm{MIC}, 1 \times \mathrm{MIC}$ or $2 \times \mathrm{MIC})$ in $\mathrm{MHB}$. Untreated cells were used as growth controls. The cultures were then incubated in a shaker at $37^{\circ} \mathrm{C}$ for $24 \mathrm{~h}$. Each sample was placed in a separate vial, and cells from each tube were harvested by centrifugation. A $2.5 \%$ glutaraldehyde solution was used to prefix all samples overnight at $4{ }^{\circ} \mathrm{C}$. Thereafter, the samples were rinsed 3 times with PBS, and postfixed in $1 \%$ osmium tetroxide in the same buffer for an hour. This was followed by 4 further rinses with PBS. After fixation, a graded series of acetone was used to dehydrate the specimens with $100 \%$ acetone being used for the final step. The specimens were then mounted and coated with gold before examination by scanning electronic microscopy (JOEL Tsm-700 FSHL, Japan).

\section{RESULTS}

\section{Time-kill profiles}

Time-kill assays allow antibacterial agents to be classified as bacteriostatic or bactericidal, and characterization of the relationship between agent concentration and activity over time. The results obtained with the mycelial extract and two S. aureus strains (MSSA strain DMST 2933 and MRSA strain DMST 20651) are shown in Figure 1. The increase in viable count of bacteria in the
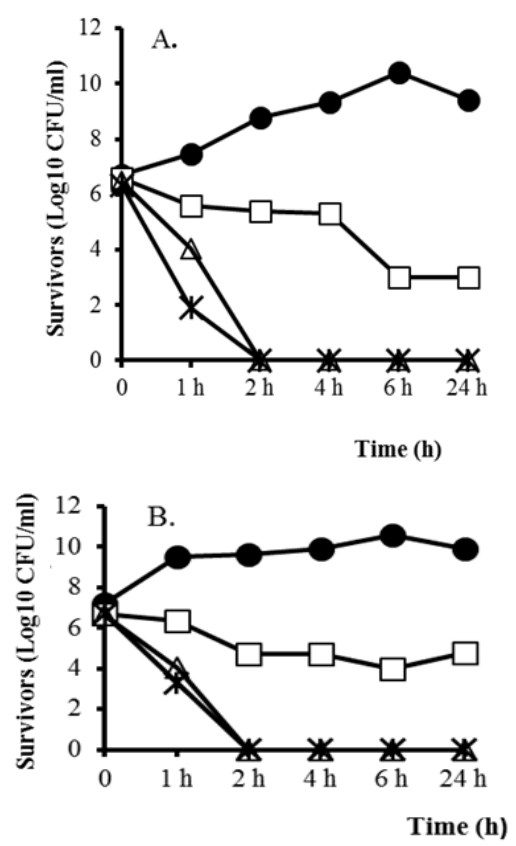

Figure 1: Time-kill profiles for $S$. aureus (MSSA) DMST 2933 (A) and S. aureus (MRSA) DMST 20651 (B) in Mueller-Hinton broth during treatment with 1.56 $\mathrm{mg} / \mathrm{mL}(0.5 \times \mathrm{MIC}), 3.125 \mathrm{mg} / \mathrm{mL}(1 \times \mathrm{MIC})$ and 6.25 $\mathrm{mg} / \mathrm{mL}(2 \times \mathrm{MIC})$ crude $P$. nipponica Cod-MK1201 mycelial extract. $\bullet$ : untreated control; $\square: 0.5 \times \mathrm{MIC}$; $\Delta: 1 \times$ MIC; $\mathbf{X}: 2 \times$ MIC control group shows these bacteria were actively growing from 1 to $24 \mathrm{~h}$. After $24 \mathrm{~h}$ incubation with $0.5 \times$ MIC $(1.56 \mathrm{mg} / \mathrm{mL})$ of the extract, a 3 $\log _{10} \mathrm{CFU} / \mathrm{mL}$ reduction in viability of $S$. aureus DMST 2933 occurred (Figure 1A), indicating the extract is bactericidal against this strain of MSSA. Comparable results were not obtained with $0.5 \times$ MIC extract and $S$. aureus DMST 20651 (Figure 1B), indicating this concentration of extract is bacteriostatic against MRSA.

At a concentration of $1 \times$ MIC $(3.125 \mathrm{mg} / \mathrm{mL})$, however, the extract was bactericidal against both tested organisms by $24 \mathrm{~h}$. Also, increasing the concentration to $2 \times \mathrm{MIC}(6.25 \mathrm{mg} / \mathrm{mL})$ resulted in bactericidal activity against MSSA by $1 \mathrm{~h}$ (Figure 1A). Complete elimination of both test strains was achieved by $2 \mathrm{~h}$ treatments with $1 \times \mathrm{MIC}$ and $2 \times \mathrm{MIC}$ extract. These results indicate that bactericidal activity of the extract is both time- and concentration-dependent.

\section{Morphological characteristics}

Samples of $P$. nipponicus mycelial extracttreated $S$. aureus were examined by SEM to detect any physical changes in appearance of the cells. SEM micrographs of $S$. aureus after 24 $\mathrm{h}$ treatment with various concentrations $(0.5 \mathrm{x}$ MIC, $1 \times$ MIC and $2 \times \mathrm{MIC}$ ) of the extract revealed considerable morphological alterations to both the MSSA and MRSA strains (Figure 2 and Figure 3). Figure 2 shows the SEM images of treated and untreated control samples of $S$. aureus (MSSA) DMST 2933. Untreated cells were intact, smooth, and of normal coccal morphology (Figure 2A). The destructive effects of the extract on test bacteria can be seen in Figure 2B-D. Bulges are present at the cell surface and debris is observed, much more so than in the untreated control cells.

Characteristic morphological alterations observed in S. aureus (MRSA) DMST 20651 treated with mycelial extract are shown in Figure 3. Exposure to $0.5 \times \mathrm{MIC}, 1 \times \mathrm{MIC}$ and $2 \times \mathrm{MIC}$ of the mycelial extract for $24 \mathrm{~h}$ led to damage of the cell wall (Figure 3B-3D), as indicated by bulging at the cell surface. Untreated control cells, by comparison, had a smooth surface (Figure 3A). When MRSA was treated with 6.25 $\mathrm{mg} / \mathrm{mL}(2 \times \mathrm{MIC})$ of the extract, cell morphology and surface appearance were dramatically altered (Figure 3D). Whilst the samples were not prepared in a quantitative manner, it is clear from the micrographs that the number of damaged cells in the treated vials greatly outnumbers those in the control vials. These results indicate that the active compound had some effect on the cytoplasmic membrane and cell wall of bacteria. 

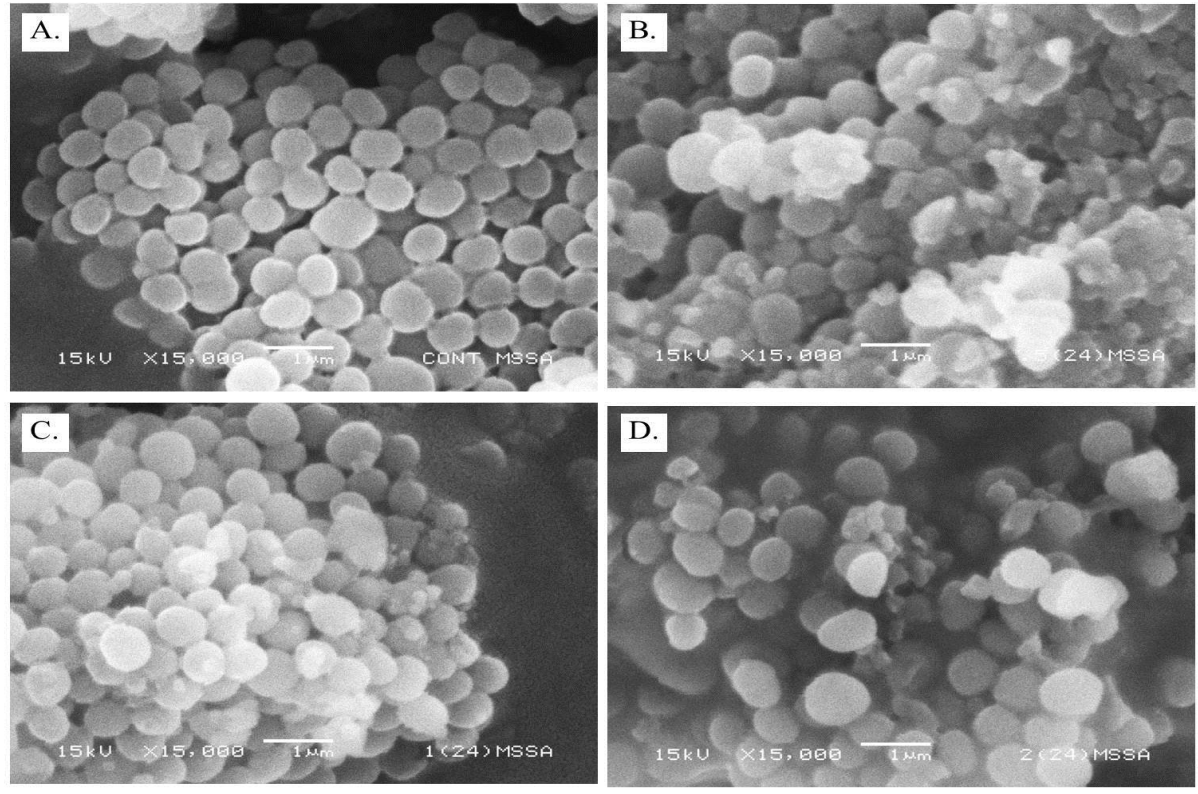

Figure 2: SEM micrographs of $S$. aureus (MSSA) DMST 2933 after $24 \mathrm{~h}$ incubation with crude $P$. nipponicus mycelial extract. (A) Untreated cells (control), and cells treated with (B) $0.5 \times \mathrm{MIC}(1.56 \mathrm{mg} / \mathrm{mL}),(\mathrm{C}) 1 \times \mathrm{MIC}$ $(3.125 \mathrm{mg} / \mathrm{mL})$, and (D) $2 \times \mathrm{MIC}(6.25 \mathrm{mg} / \mathrm{mL})$ extract. Magnification, $\times 15,000$
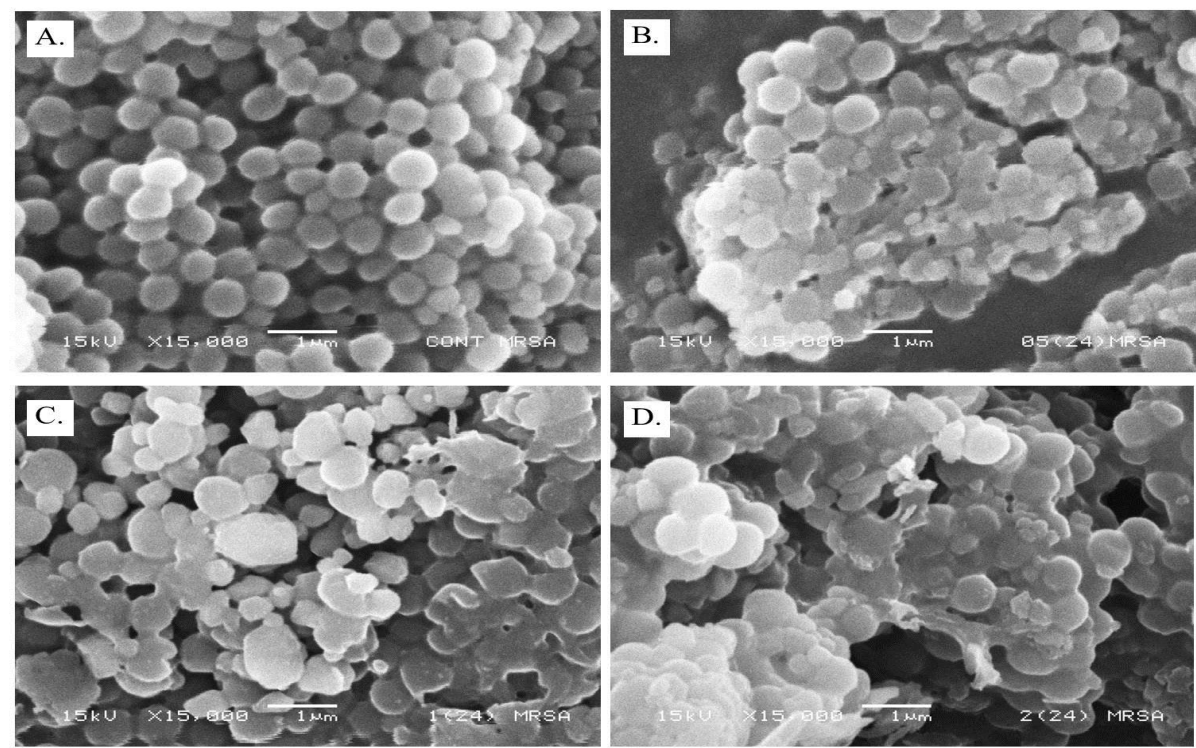

Figure 3: SEM micrographs of $S$. aureus (MRSA) DMST 20651 after $24 \mathrm{~h}$ incubation with crude $P$. nipponicus mycelial extract. (A) Untreated cells (control), and cells treated with (B) $0.5 \times \mathrm{MIC}(1.56 \mathrm{mg} / \mathrm{mL}),(\mathrm{C}) 1 \times \mathrm{MIC}$ $(3.125 \mathrm{mg} / \mathrm{mL})$, and (D) $2 \times$ MIC $(6.25 \mathrm{mg} / \mathrm{mL})$ extract. Magnification, x 15,000

This could have been caused by an alteration in cytoplasmic membrane permeability, leading to cell wall leakage.

\section{DISCUSSION}

Increases in the incidence of multidrug-resistant $S$. aureus infections have prompted renewed efforts to identify biologically active molecules from natural sources that might be useful antibacterial therapies. Several Cordyceps species extracts, including those from $C$. sinensis [15], C. militaris [10], C. sobilifera [9], and C. taii
[14], have been reported to have potent antibacterial activity against human pathogenic bacteria. In a previous study, we demonstrated the antibacterial effects of an ethanolic mycelial extract of P. nipponicus Cod-MK1201 against MSSA and MRSA strains. Because the MIC and $M B C$ values of the extract were quite low (3.125 $\mathrm{mg} / \mathrm{mL}$ ) [16], it was decided that further characterization would be useful. Therefore, the present study determined the time-kill profiles and morphological effects of the extract against MSSA and MRSA. The findings obtained represent the first published information on the 
microbial death kinetics and possible mechanism of action of $P$. nipponicus mycelial extract against antibiotic -susceptible and -resistant strains of $S$. aureus.

The time-kill assay is an important method for determining the potency of bioactive extracts, and determining whether these are bactericidal or bacteriostatic. The present study analyzed bacterial viability over time during treatment with various concentrations of $P$. nipponicus mycelial extract. At sub-inhibitory levels $(0.5 \times \mathrm{MIC})$, the extract had bactericidal activity against MSSA, and bacteriostatic activity against MRSA. The mycelial extract at a concentration equal to $2 x$ MIC was rapidly bactericidal, achieving complete elimination of both test bacterial strains within 2 h. All of the time-kill data obtained with the $P$. nipponicus mycelial extract showed its antibacterial activity to be time - and concentration-dependent. This finding correlates with that of Okemo et al [21], who found that Ximenia caffra extracts kill $S$. aureus in both a time- and concentration-dependent manner. Also, extracts of the endophytic fungus Nigrospora sphaerica CL-OP30 are active against $S$. aureus in a time- and concentrationdependent manner during the first $12 \mathrm{~h}$ of treatment [22].

In addition to the time-kill data obtained, the effect of the $P$. nipponicus mycelial extract $(0.5 \mathrm{x}$ MIC, $1 \times$ MIC and $2 \times \mathrm{MIC}$ ) on $S$. aureus morphology was determined by SEM. Perturbations to cell surface morphology could be detected when MSSA and MRSA were treated with various concentration of the mycelial extract. Scanning electron microscopy images captured at 15,000x magnification clearly show cell surface and morphological changes such as bulges, surface disruption, and broken cells. These alterations may be due to phenolic or other bioactive compounds present in the mycelial extract affecting the cell wall and cytoplasmic membrane of $S$. aureus, thereby causing leakage of bacterial cell contents and eventual cell lysis $[16,23]$. Similar results have been described in a study where $S$. aureus cells were treated with Nigrospora sphaerica CL-OP30 extract. The authors attributed the formation of cavities, surface alterations, and appearance of collapsed and shrunken cells to leakage of cytoplasmic contents [22]. Similar cell wall effects have been reported in $S$. aureus treated with bacteria-derived antibiotics [24,25].

\section{CONCLUSION}

The results of this study reveal that $P$. nipponicus Cod-MK1201 mycelial extract exhibits significant in vitro antibacterial activity against staphylococci. These entomopathogenic fungi may therefore be suitable candidates for bioprospecting for antimicrobial drugs. Further studies will be required to isolate and identify the bioactive compounds present in $P$. nipponicus Cod-MK1201, and determine whether they could be developed as novel drugs for the treatment of antibiotic-resistant bacterial infections.

\section{DECLARATIONS}

\section{Acknowledgement}

The authors thank Mahasarakham University Faculty of Medicine for financial support and language-editing assistance, and Mahasarakham University Faculty of Science for provision of laboratory space and equipment.

\section{Conflict of Interest}

No conflict of interest associated with this work.

\section{Contribution of Authors}

The authors declare that this work was done by the authors named in this article and all liabilities pertaining to claims relating to the content of this article will be borne by them.

\section{Open Access}

This is an Open Access article that uses a funding model which does not charge readers or their institutions for access and distributed under the terms of the Creative Commons Attribution License (http://creativecommons.org/licenses/by 14.0) and the Budapest Open Access Initiative (http://www.budapestopenaccessinitiative.org/rea d), which permit unrestricted use, distribution, and reproduction in any medium, provided the original work is properly credited.

\section{REFERENCES}

1. Lowy FE. Staphylococcus aureus infections. $N$ Engl J Med 1998; 339(8): 520-532.

2. Beam JW, Buckley B. Community-acquired methicillinresistant Staphylococcus aureus: Prevalence and risk factors. J Athl Train 2006; 41: 337-340.

3. Swartz MN. Hospital-acquired infections: diseases with increasingly limited therapies. Proc Natl Acad Sci USA 1994; 91: 2420-2427.

4. Hiramatsu K. Vancomycin-resistant Staphylococcus aureus: a new model of antibiotic resistance. Lancet Infect Dis 2001; 1: 147-155.

Trop J Pharm Res, February 2017; 16(2): 411 
5. Liu C, Chambers FH. Staphylococcus aureus with heterogeous resistance to vancomycin: epidemiology, clinical significance and critical assessment of diagnostic methods. Antimicrob Agents Chemother 2003; 47: 3040-3045.

6. Cookson BD, Balton MC, Platt JH. Chlorhexidine resistance in methicillin-resistant Staphylococcus aureus or just and elevated MIC? An in vitro and in vivo assessment. Antimicrob Agents Chemother 1991; 35(10): 1997-2002.

7. Kampf G, Jarosch R, Ruden H. Limited effectiveness of chlorhexidine based hand disinfectants against methicillin-resistant Staphylococcus aureus (MRSA). J Hosp Infect 1998; 38: 297-303.

8. Fritz SA, Hogan PG, Camins B, Ainsworth AJ, Patrick C, Martin MS, Krauss MJ, Rodriguez M, Burnham CAD. Mupirocin and chlorhexidine resistance in Staphylococcus aureus in patients with communityonset skin and soft tissue infections. Antimicrob Agents Chemother 2013; 57(1): 559-568.

9. Imtiaj A, Lee TS. Screening of antibacterial and antifungal activities from Korean wild mushrooms. World $J$ Agric Sci 2007; 3: 316-321.

10. Reis FS, Barros L, Calhelha RC, Ćirić A, van Griensven LJLD, Soković M, Ferreira ICFR. The methanolic extract of Cordyceps militaris (L.) Link fruiting body shows antioxidant, antibacterial, antifungal and antihuman tumor cell lines properties. Food Chem Toxicol 2013; 62: 91-98.

11. Wang SY, Shiao MS. Pharmacological Functions of Chinese Medicinal Fungus Cordyceps sinensis and Related Species. J Food Drug Anal 2000; 8(4): 248-257.

12. Won SY, Park EH. Anti-inflammatory and related pharmacological activities of cultured mycelia and fruiting bodies of Cordyceps militaris. J Ethnopharmacol 2005; 96(3): 555-561.

13. Seth R, Haider SZ, Mohan M. Pharmacology, phytochemistry and traditional uses of Cordyceps sinensis (Berk.) Sacc: A recent update for future prospects. Indian J Traditional Knowledge 2014; 13(3): 551-556.

14. Xiao JH, Xiao DM, Sun $Z H$, Xiong $Q$, Liang $Z Q$, Zhong $J J$. Chemical compositions and antimicrobial property of three edible and medicinal Cordyceps species. J Food Agric Environ 2009; 7: 91-100.

15. Zheng $H$, Maoqing $Y$, Liqiu $X$, Wenjuan $T$, Liang L, Guolin $Z$. Purification and characterization of an antibacterial protein from the cultured mycelia of Cordyceps sinensis. Wuhan University J Nat Sci 2006; 11:709-714.

16. Sangdee K, Nakbanpote W, Sangdee A. Isolation of the entomopathogenic fungal strain Cod-MK1201 from a cicada nymph and assessment of its antibacterial activities. Int J Med Mushrooms 2015; 17(1): 51-63.

17. Sangdee $K$, Seephonkai $P$, Buranrat B, Surapong $N$, Sangdee $A$. Effects of ethyl acetate extracts from Polycephalomyces nipponicus isolate Cod-MK1201 (Ascomycetes) against human pathogenic bacteria and a breast cancer cell line. Int J Med Mushrooms 2016; 18(8): 733-743.

18. Sangdee $K$, Thummabenjapone $P$, Sangdee $A$. Evaluation of antigen preparation methods for polyclonal antibody production against Streptomyces spp. $\mathrm{Br}$ Microbiol Res J 2012; 2(3): 137-45.

19. White RL, Burgess DS, Manduru M, Bosso JA. Comparison of three different in vitro methods of detecting synergy: time-kill, checkerboard, and E test. Antimicrob Agents Chemother 1996; 40(8): 1914-1918.

20. Aiyegoro OA, Afolayan AJ, Okoh Al. In vitro antibacterial time kill studies of leaves extracts of Helichrysum longifolium. J Med Plant Res 2009; 3(6): 462-467.

21. Okemo PO, Mwatha WE, Chhabra SC. The kill kinetics of Ximenia caffra sond. (Olacaceae) extracts against selected bacteria and fungi. J Trop Microbiol Biotechnol 2004; 3(1): 88-94.

22. Ibrahim D, Lee CC, Yenn TW, Zakaria L, Sheh-Hong L. Effect of the extract of endophytic fungus, Nigrospora sphaerica CL-OP 30, against the growth of methicillinresistant Staphylococcus aureus (MRSA) and Klebsiella pneumonia cells. Trop J Pharm Res 2015; 14(11): 2091 2097.

23. Johnston MD, Hanlon GW, Denyer SP, Lambert RJW. Membrane damage to bacteria caused by single and com $\neg$ bined biocides. J Appl Microbiol 2003; 94: 10151023.

24. Sianglum W, Srimanote $P$, Wonglumsom W, Kittiniyom K, Voravuthikunchai SP. Proteome analyses of cellular proteins in methicillin-resistant Staphylococcus aureus treated with rhodomyrtone, a novel antibiotic candidate. Plos One 2011; 6:e16628.

25. Darabpour E, Ardakani MR, Motamedi H, Ronagh MT. Isolation of a potent antibiotic producer bacterium, especially against MRSA, from northern region of the Persian Gulf. Bosnian J Basic Med Sci 2012; 12: 108121. 